\title{
Genotoxicity and toxicity evaluations of ECF cellulose bleaching effluents using the Allium cepa $\mathbf{L}$. Test
}

\author{
Roa, O. ${ }^{a}$, Yeber, MC. ${ }^{a *}$ and Venegas $W^{b}$ \\ ${ }^{a}$ Faculty of Science, Universidad Católica de la Santísima Concepción, P.O. Box 297, Concepción, Chile \\ ${ }^{b}$ Department of Cellular Biology, Universidad de Concepción, P.O. Box 160-C, Concepción, Chile \\ *e-mail: mcyeber@ucsc.cl
}

Received July 5, 2011 - Accepted August 22, 2011 - Distributed August 31, 2012

(With 5 figures)

\begin{abstract}
Toxicity and genotoxicity tests were performed on root cells of Allium cepa in order to evaluate wastewater quality following an ECF cellulose bleaching process. The results revealed a toxic effect of the effluent, with inhibition of meristem growth and generally lower values of metaphase, anaphase and telophase indices at $\mathrm{pH} 10.5 \mathrm{fhan} \mathrm{pH} 7 \mathrm{for}$ all effluent concentrations. The genotoxicity effect was different from the toxic effect given that the micronucleus and the chromosomal aberration tests in anaphase-telophase cells were low over all ranges of the studied effluent concentrations.
\end{abstract}

Keywords: Allium cepa, toxicity, genotoxicity, ECF bleaching effluent, Kraft cellulose.

Genotoxicidade e toxicidade em Allium cepa L.: avaliação da qualidade do efluente no processo de branqueamento da celulose

\begin{abstract}
Resumo
Os testes de toxicidade e genotoxicidade foram realizados em células da raiz de Allium cepa, a fim de avaliar a qualidade do efluente na sequência de um processo de branqueamento de celulose ECF. Os resultados revelaram um efeito tóxico do efluente, com inibição de crescimento do meristema e valores geralmente baixos de metáfase, anáfase e índices de telófase, a pH 10,5 e pH 7, para todas as concentrações do efluente. O efeito de genotoxicidade foi diferente do efeito tóxico, uma vez que o micronúcleo e os testes de aberrações cromossômicas em anáfase-telófase das células foram baixos em todas as gamas de concentrações do efluente estudado.
\end{abstract}

Palavras-chave: Allium cepa, toxicidade, genotoxicidade, branqueamento por sequências ECF, Kraft celulose.

\section{Introduction}

Pulp and paper mill effluents are constant sources of discharge of a complex mixture of organic pollutants, which produce aquatic contamination and impact human health. Examples of this type of contamination are given by various authors (Grant, 1982; Blavk and Bauman, 1991; Garcia et al. 1995; Bowron et al., 2009; Diniz et al., 2010; MacLatchy et al., 2010; Kulshreshtha et al., 2011), who report that the cellulose and paper industry release a large quantity (i.e. metric tons) of chemical agents into aquatic areas. Many of these agents are mutagens, and some are carcinogenic for humans. Thus, scientific studies have detected both toxic and genotoxic effects caused by the liquid effluents dumped into the aquatic environment. The common onion, Allium cepa $\mathrm{L}$. $(2 \mathrm{n}=16)$, constitutes a very convenient test system for estimating the harmful effects of chemicals on biological materials. The A. cepa assay is an efficient test for chemical screening and in situ monitoring of the genotoxicity effect of environmental contaminants (Fiskesjö, 1985, 1993; Barbérico et al., 2009; Siddiqui et al., 2011; Nunes et al., 2011). This test has been widely used to study the toxicity and genotoxicity of many dangerous contaminants, such as pesticides, azo dyes, food preservatives and hydrocarbons (Riffat and Ahmad, 2006; Mittergger et al., 2007; Feretti et al., 2007; Türkoğlu, 2007; Leme and Marin-Morales, 2008; Mustafa and Arikan, 2008; Ashraf and Husain, 2010), where all tests have shown that $A$. cepa is more sensitive for detecting toxicity and genotoxicity than other tests. Studies conducted with real effluents obtained from a textile mill revealed that water contaminated with azo dyes induces chromosomal and nuclear aberrations in A. cepa (Caritá and Marin, 2008; Leme and Marin-Morales, 2009). Pulp and paper mill effluents are a complex mixture of organic compounds derived from lignin (Quevedo et al., 1994; 
Strömberg et al., 1996; Xavier et al., 2011) However, today mills have made significant changes in their processes, partially or totally eliminating elemental chlorine as a bleaching agent. This bleaching sequence, known as Elemental Chlorine Free (ECF) or Totally Chlorine Free (TCF), achieves the reduction of organochloride compounds, such as Absorbable Organic Compounds (AOX), however, toxic and inhibitory organic compounds continue to be present in the effluents. Therefore, in this study, we use the Allium cepa test to evaluate the toxicity and genotoxicity of a Kraft ECF bleaching effluent.

\section{Material and Methods}

\subsection{Effluent collecting}

The effluent was obtained from the bleaching sequence of Kraft cellulose from radiata pine (Pinus radiata) Kraft cellulose from an industry, specifically obtained from the first extraction stage of the ECF bleaching sequence (E1). Prior to its use, the effluent was left at room temperature $\left(18-20^{\circ} \mathrm{C}\right)$. The first stage of this study consisted of evaluating the effluent concentrations: the preliminary study began with toxicity assays, evaluating three concentrations (100\%, $50 \%$, and $25 \%$ ), but due to high toxicity we added a fourth concentration of $6.25 \%$. Spring water was used for the dilutions and, prior to each treatment, the $\mathrm{pH}$, temperature, and conductivity were measured with VARIO CAND SET WTW 2X00-001A equipment. The compounds present in the effluent were analyzed on a Shimadzu AOC-5000 gas chromatography-mass spectrometer (GC/MS).

\subsection{Toxicity assay}

For the acute toxicity assay, 42 dry Allium cepa bulbs (5-6 cm diameter) with no leaf or root formation were selected. Prior to the experimental set up (Figure 1), the bulbs were cleaned, to eliminate the dried epidermis, using a scalpel to remove the tissue remains and dry roots from around the root area, avoiding damage to the primary roots. For the experiment, 42 flasks, each with an $80 \mathrm{~mL}$ capacity, were divided into six groups of seven flasks. Each group was labelled according to the concentration of the experimental dilutions: $100 \%, 75 \%, 50 \%, 25 \%, 6.25 \%$, and the corresponding negative control (spring water). Simultaneously, a positive control was set apart to detect whether this protocol provides a feasible way to evaluate the toxicity of effluents. The positive control required the use of 42 bulbs (prepared as above) with different $\mathrm{CuSO}_{4}$ solutions (10, 20, 40, 80, and $100 \mathrm{mg} / \mathrm{L}$ ) (Rank et al., 2002). In the initial stage of assembly of the test, we selected a copper sulfate soluble compound, purity $\geq 99 \%$, which was subjected to toxicity tests to establish the concentration range that produces the desired effect. The dose-response curve was used as a toxicant reference. Given that this is a semi-static assay, it was left at room temperature $\left(18-20^{\circ} \mathrm{C}\right)$, with indirect light, for 72 hours. Observations were made once a day in order to detect possible volume loss due to evaporation or absorption during the treatment.
At the end of the exposure period, we recorded a root length using a calliper. With this technique, we made an estimate of the minimum and maximum length of the roots in each graduated flask, and used the mid-point. The data were entered into the TOXSTAT program version 3.4 in order to evaluate test assumptions and to determine the concentration for which there were significant differences in order to infer that the effluent significantly inhibited the growth of the bulb roots.

\subsection{Mitotic index determination}

The mitotic index was calculated by quantifying 2,000 cells in a cellular preparation (three slides $=6,000$ total cells) observed under a Zeiss binocular microscope Standard R.A. The cells were classified according to their stage in the cellular cycle (i.e. interphase, prophase, metaphase, anaphase or telophase). These data were used to calculate the indices for evaluating toxicity at the cellular level, using the following formulae:

Mitotic index $(\%)=$ Number of cells in mitosis $\times 100 /$ total number of cells

Calculation of the Phase Index:

Index in each phase $(\%)=$ Number of cells in each phase $\times 100 /$ total number of cells in mitosis

\subsection{Genotoxicity assays}

In this experiment, we used $A$. cepa bulbs exposed to the same effluent concentrations as above $(100 \%, 75 \%$, $50 \%, 25 \%$, and $6.25 \%$ ), as well as a negative control using spring water and a positive control using $10 \mathrm{mg} . \mathrm{L}^{-1}$ of methyl methanesulfonate (MMS) (Rank et al., 2002).

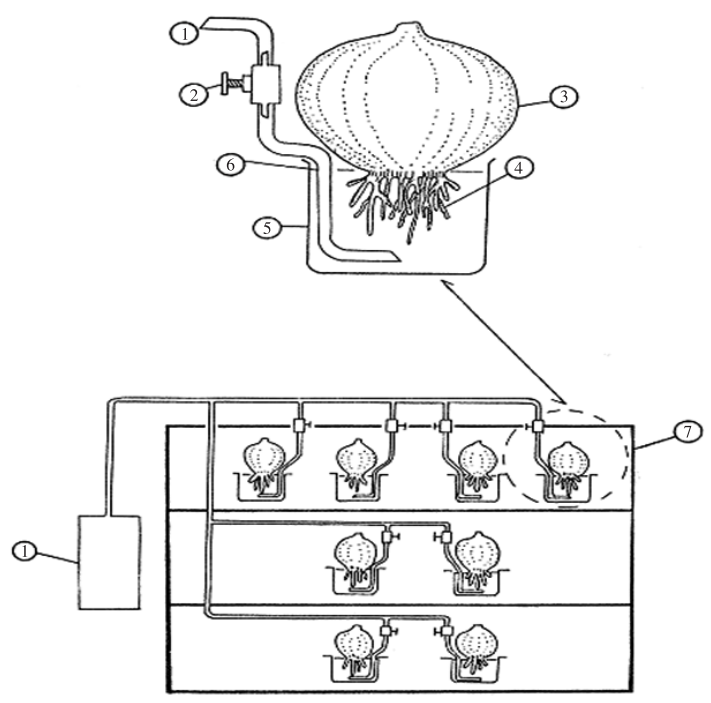

Figure 1. Schematic of the set-up of the culture chamber and treatments of the apical meristems of Allium cepa roots. The upper drawing shows an individual Allium cepa bulb culture chamber, while the lower drawing depicts the entire chamber. Numbers indicate: 1) air pump; 2) regulation valve; 3) Allium cepa bulb; 4) roots; 5) glass receptacle; 6) level of liquid sample in the study; 7) individual culture chamber. 
Each experimental concentration was replicated in triplicate. During the first part of the experiment, the meristems were left for 46 hours to allow for germination in $100 \mathrm{~mL}$ graduated flasks, placed in a dark chamber, at room temperature, under continuous aeration. For each treatment, we quantified the presence of micronuclei (MN) during interphase and chromosomal aberrations (CA) during anaphase-telophase (A-T). The experiment was conducted in a dark chamber with a continuous aeration system.

After the germination period, the best apical meristems were selected from each concentration and replicate. The selected meristems were cut and placed in small flasks with Carnoy's fixative (3:1, absolute alcohol:acetic acid) for 24 hours. The meristems were then washed in distilled water and subjected to acid hydrolysis in a test tube for 10 minutes at $60{ }^{\circ} \mathrm{C}$ in a double boiler. Following this period, the test tube was quickly cooled using tap water in order to stop the hydrolysis and the meristems were then washed with distilled water.

The cell nuclei were stained with Schiff's reagent for 20 to 30 minutes. Each apical meristem was then macerated in $30 \%$ acetic acid and deposited on a slide. In order to separate the cover from the slide without harming the sample, it was frozen on dry ice. The cytological preparations were then examined under a photomicroscope to determine the MN frequency by quantifying the percentage of chromosome aberrations in A-T in 1000.

\section{Results and Discussion}

The initial conditions of the effluent were as follows: temperature of $18{ }^{\circ} \mathrm{C}$, conductivity $0.56 \mathrm{~K} \Omega / \mathrm{cm}$, and $\mathrm{pH} 10.5$. Since the initial $\mathrm{pH}$ of the effluent was alkaline, for adequate performance of the toxicity test it was necessary to add a test at $\mathrm{pH} 7.0$ in order to normalize the experiment.

The analysis of the results showed a clear toxic effect of the studied effluents, as reflected in the inhibition of meristem growth, when the bulbs were stimulated to grow under higher concentrations of the effluent. This finding was corroborated with the results of finer cellular toxicity studies, which showed a decrease in the mitotic index when the $A$. сера apical meristems were divided and exposed to a high concentration environment, as was the case of the initial effluent concentration (100\%) (Figure 2). On the other hand, the metaphase, anaphase, and telophase indices presented results in accordance with those indicated earlier; that is, a noteworthy decrease of the phase indices as the effluent concentrations increased (Figure 3). The opposite pattern was observed in the results obtained from the genotoxicity studies. In fact, the MN frequency and percentage of chromosomal aberrations in A-T were unexpectedly low (Table 1), indicating that the industrial analyzed effluent is toxic but does not have genotoxic properties.

In order to evaluate the possible effect of the $\mathrm{pH}$, toxicity and genotoxicity studies were performed at $\mathrm{pH} 10.5$ and $\mathrm{pH} 7$ in order to establish differences in the results of toxicity and genotoxicity under both conditions. The results obtained in this experimental design indicated that the effluent was clearly more toxic at $\mathrm{pH} 10.5$ than at $\mathrm{pH} 7$, with significant differences in the acute toxicity assay. The same tendency was observed in the cellular toxicity test; however in this case, the results were more related to the $\mathrm{pH}$ of the original effluent than to the presence of genotoxic components in the complex mixture of chemical substances present in the effluent. With respect to the genotoxicity assay, it is interesting to note that $\mathrm{MN}$ frequencies and chromosome aberrations were found in anaphase-telophase were greater at $\mathrm{pH} 7$ than at $\mathrm{pH} 10.5$ (Table 1). This indicates that at $\mathrm{pH} 10.5$, the effluent produces a toxic effect in relation to the cell division, either inhibiting it or promoting a lengthening of the cellular cycle, but does not have a genotoxic effect. The photomicrographs show the presence of MN found in Allium cepa cells during interphase (Figure 4a), and chromosomal aberrations consisting of acentric fragments, rings and acentric chromosomes (Figures 4b, c, and d). Micronuclei (MN) were present in more than $50 \%$ of cells at high effluent concentrations (i.e. $100 \%, 75 \%$ ) at $\mathrm{pH} 7$, while at $\mathrm{pH} 10.5$, percentages fell to below $25 \%$ but were also present at low effluent concentrations (25\%) (Table 1). Chromosomal aberrations (CA) in A-T were present at all concentrations except the control (0 effluent), and were higher at $\mathrm{pH} 7$ than $\mathrm{pH} 10.5$ (Table 1). We observed significant differences in prophase, metaphase, anaphase and telephase indices, however the mitotic index was highly variable for both factors and no significant differences were observed for this index (Figure 2). For the majority of these indices, we observed a significant interaction between concentration and $\mathrm{pH}$, which were generally higher at $\mathrm{pH} 10.5$ than at $\mathrm{pH} 7$ for different concentrations of effluent (Figure 3). It should be considered that decreasing the $\mathrm{pH}$ from 10.5 to pH 7 might allow potential clastogenic agents present in the complex mixture to be masked by the $\mathrm{pH}$ and to act on the hereditary material, damaging it through complex molecular mechanisms related to changes in $\mathrm{pH}$.

By chromatographic analysis (Figure 5), it was possible to identify two chlorinated compounds (biphenyl-2,

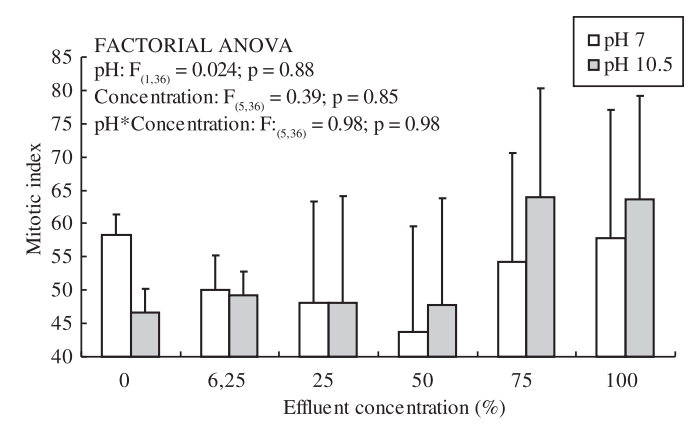

Figure 2. Mitotic index values of Allium cepa exposed to different concentrations of kraft pulp effluent, at $\mathrm{pH} 7$ (white bars) and $\mathrm{pH} 10.5$ (gray bars). Given the high variability of this index in all treatments, no significant differences were observed. 
7-dichloride methylene-4, 5-dicarboxylic and anhydride biphenyl-2-chlorophenyl-4, 5-phthalic). The environmental consequences of these emissions could be serious. Much research conducted near industries with these chlorinated compounds in their effluents has detected a high frequency of anomalous fish with neoplasia (Vogelbein et al., 1990; Ohe et al., 2004; Misik et al., 2011).

Given that government agencies worldwide have adopted legislation to reduce the emissions of toxic waste from industries, many researchers have made efforts using modern technology to protect the aquatic environment. This provides some degree of optimism with respect to improvements in the interface between industry and the environment and potential solutions for cleaning-up the aquatic environment. Nevertheless, scientists and researchers should always be alert since molecules that have not been eliminated by the different treatments applied to effluents from the cellulose industry, and which are considered to be harmless to the aquatic biota, could produce various changes and/or modifications at the molecular and cellular levels in organisms that inhabit these environments.
These changes can range from alterations in metabolic functions, such as enzymatic detoxification activity, to alterations in the reproductive system. These molecules, called endocrine disruptors, have been detected in effluents from the cellulose industry (Venegas et al., 1994, 1995; Wang et al., 2008; Kovacs et al., 2011). Since these molecules have a chemical structure similar to steroid molecules, they can cause exaggerated growth of immature oocytes of native fish and other aquatic organisms, and alter their reproductive performance. The specific effects of these molecules on organisms are variable since these biological effects are exerted in the context of a genotypeenvironment interaction.

It is essential to make clear that both in toxicology and in vivo studies of genotoxicity of samples from continental aquatic environments, the use of the plant model, Allium cepa has several advantages given that it is easy to manipulate, it is sensitive to rapid response bioassays, it is cheap, and, most importantly, it has a good correlation with models that use mammalian cells for this type of study (Fiskesjö, 1997; Venegas et al., 1990;
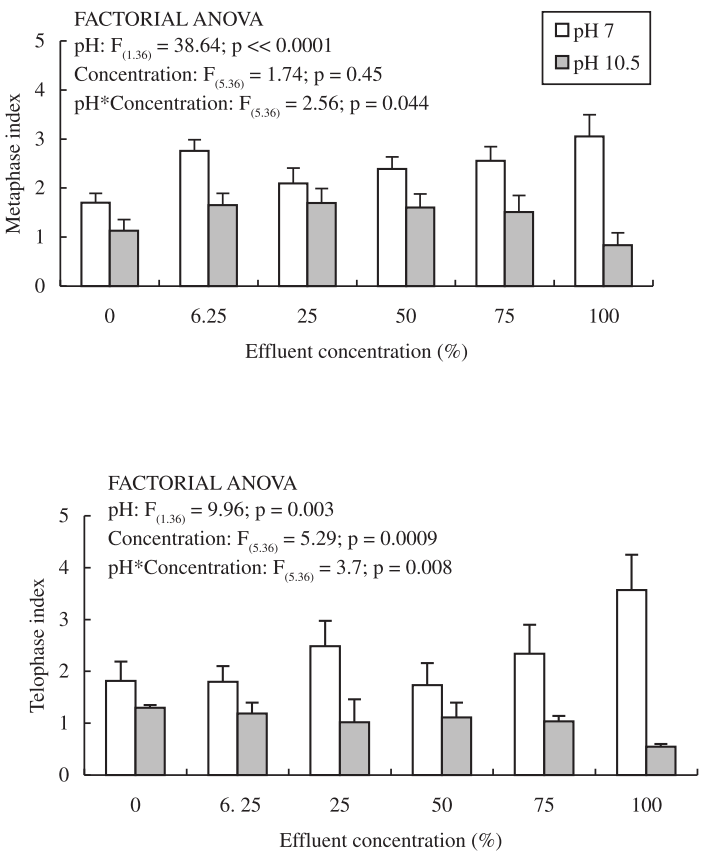

Figure 3. Responses of prophase, metaphase, anaphase and telophase indices for Allium cepa exposed to different concentrations of kraft pulp effluent, at $\mathrm{pH} 7$ (white bars) and $\mathrm{pH} 10.5$ (gray bars).

Table 1. Micronuclei frequency (MN\%o) and percentage of chromosomal aberrations (CA) under different concentrations of a liquid cellulose effluent at $\mathrm{pH} 7$ and $\mathrm{pH} 10.5$, including $(+)$ and (-) controls.

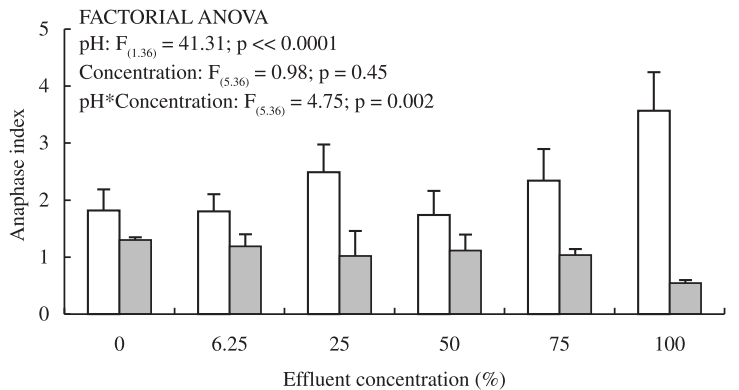

Effluent concentration

\begin{tabular}{lllccccc}
\hline & \multirow{2}{*}{$\mathbf{1 0 0 \%}$} & $\mathbf{7 5 \%}$ & $\mathbf{5 0 \%}$ & $\mathbf{2 5 \%}$ & $\mathbf{6 . 2 5 \%}$ & \multicolumn{2}{c}{ Control(-) Control(+) } \\
\cline { 7 - 9 } & & & & & & $\mathbf{1 0} \boldsymbol{\mu g} / \mathbf{L}$ \\
\hline MN\%o pH 7 & 0.75 & 0.75 & 0.25 & 0 & 0 & 0 & 7.5 \\
MN\%o pH 10.5 & 0.25 & 0.25 & 0 & 0.25 & 0 & 0 & 7.5 \\
CA in A-T pH 7 & 3.75 & 2.5 & 3.0 & 2.25 & 2.0 & 0 & 7.25 \\
CA in A-T pH 10.5 & 1.5 & 1.0 & 1.5 & 2.0 & 1.5 & 0 & 7.25 \\
\hline
\end{tabular}




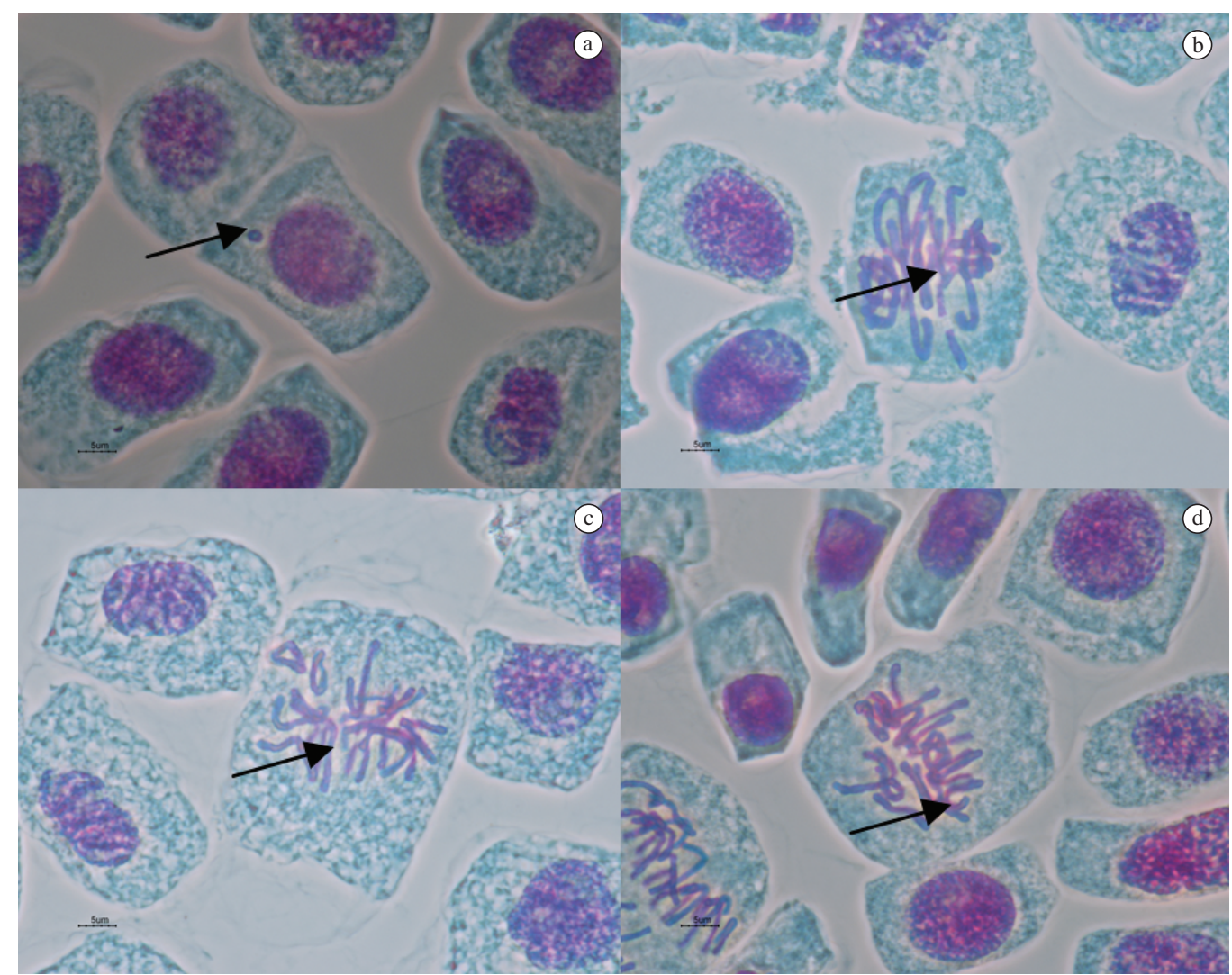

Figure 4. Photomicrograph indicating the presence of $\mathrm{MN}$ and chromosomal aberrations present in cells of Allium cepa: (a) micronucleus cell interface, (b) acentric fragment, (c) rings, and (d) acentric chromosome in anaphase-telophase.

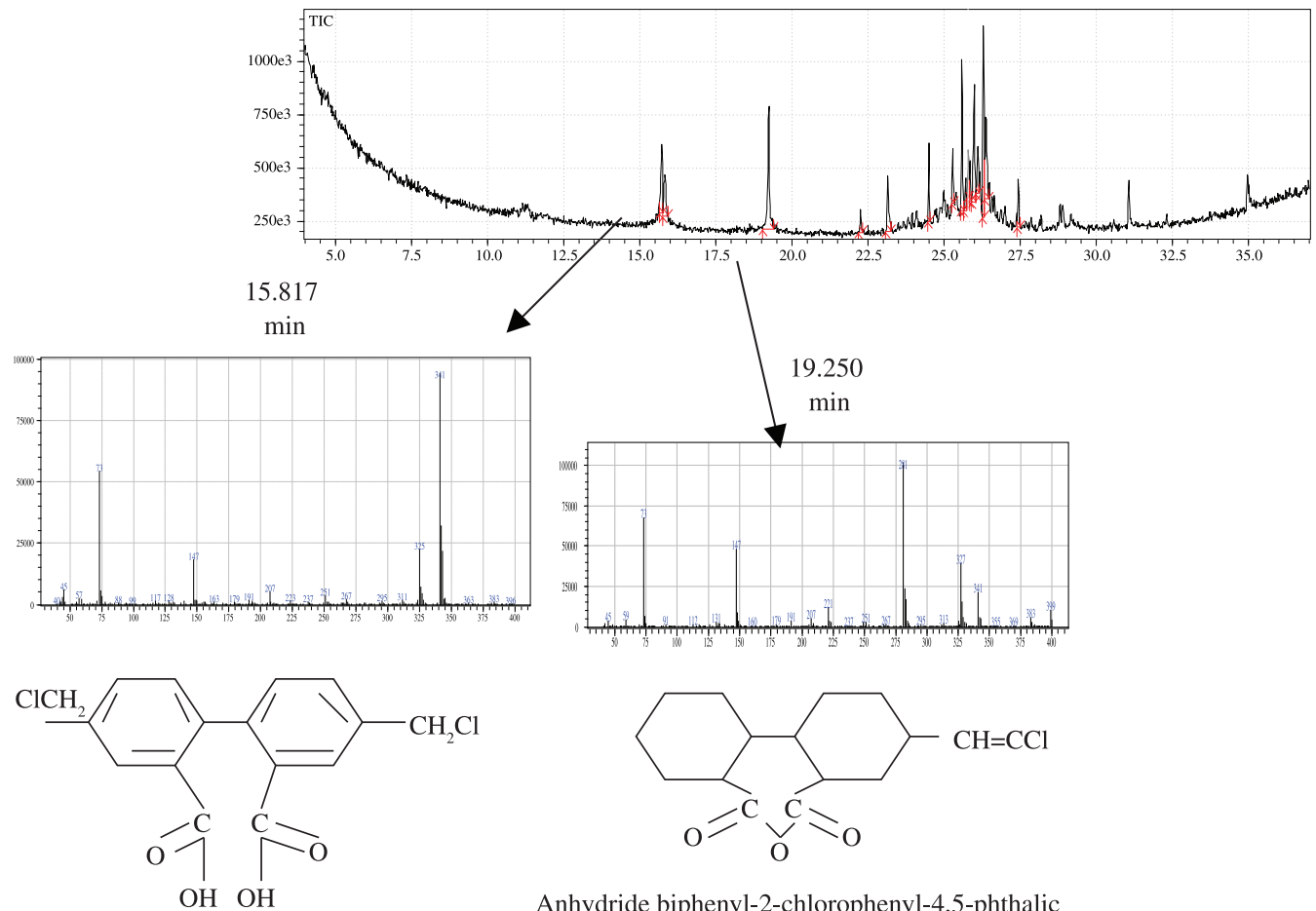

Biphenyl-2,7-dichloroethylene-4,5-dicarboxylic

Figure 5. GC-MS analysis of compounds present in an ECF cellulose effluent from stage $\mathrm{E}_{\mathrm{op}}$. 
Oberholster et al., 2008; Chaparro et al., 2010). Finally, the Allium cepa $\mathrm{L}$. test proved to be a sensitive method, representing an efficient model for detecting the effects of different contaminants on the environment, such as those associated with cellulose effluents. It is important to note that it may be possible to perform continuous monitoring using the Allium cepa L. test, thus obtaining a rapid response of the effects of contaminants in the environment. These effluents can change their toxicity due to changes in pollutant concentrations, by dilution or changes in the $\mathrm{pH}$, or due to the type of raw material used for the production of cellulose. As was observed in this study, the toxicity response was most affected by changes in the $\mathrm{pH}$, due to the high $\mathrm{pH}$ of this type of effluent.

Acknowledgements - The authors would like to thank the Faculty of Science, Universidad Católica de la Santísima Concepción and the Department of Cellular Biology, Universidad de Concepción.

\section{References}

ASHRAF, H. and HUSAIN, Q., 2010. Studies on bitter gourd peroxidise catalyzed removal of p-bromophenol from wastewater. Desalination, vol. 262, no. 1-3, p. 267-272. http://dx.doi. org/10.1016/j.desal.2010.05.044

BARBÉRICO, A., BARROS, L., VOLTOLINI, JC. and MELLO, MLS., 2009. Evaluation of the cytotoxic and genotoxic potential of water from the River Paraíba do Sul, in Brazil, with the Allium cepa L. Test. Brazilian Journal of Biology, vol. 69, no. 3, p. 837-842. PMid:19802442.

BLAVK, GC. and BAUMANN, PC., 1991. Carcinogens and cancers in freshwater fishes. Environmental Health, vol. 90, p. 27-33.

BOWRON, LK., MUNKITTRICK, KR., MCMASTER, ME., TETREAULT, G. and HEWITT, LM., 2009. Responses of white sucker (Catostomus commersoni) to 20 years of process and waste treatment changes at a bleached Kraft pulp mill and to mill shutdown. Aquatic Toxicology, vol. 95, p. 117-132. PMid:19783055. http://dx.doi.org/10.1016/j.aquatox.2009.08.009

CARITÁ, R. and MARIN, MA., 2008. Induction of chromosome aberrations in the Allium cepa test system caused by the exposure of seeds to industrial effluents contaminated with azo dyes. Chemosphere, vol. 72, p. 722-725. PMid:18495201. http://dx.doi. org/10.1016/j.chemosphere.2008.03.056

CHAPARRO, TR., BOTTA, CM. and PIRES, EC., 2010. Biodegradability and Toxicity assessment of bleach plant effluents treated anaerobically. Water Science and Technology, vol. 62, no. 6, p. 1312-1319. http://dx.doi.org/10.2166/wst.2010.944

DINIZ, MS., PERES, I., CASTRO, L., FREITAS, AC., ROCHA-SANTOS, TAP., PEREIRA, R. and DUARTE, AC., 2010. Impact of a secondary treated bleached Kraft pulp mil effluent in both sexes of goldfish (Carassius auratus L.). Journal of Environmental Science and Health, vol. 45, no. 14, p. 1858-1865. PMid:20954041. http://dx.doi.org/10.1080/10934529.2010.520517

FERETTI, D., ZERBINI, I., ZANI, C., CERETTI, E., MORETTI, M. and MONARCA, S., 2007. Allium cepa chromosome aberration and micronucleus test applied to study genotoxicity of extracts from pesticide-treated vegetables and grades. Food Additives and Contaminants, vol. 24, p. 561-572. PMid:17487597. http:// dx.doi.org/10.1080/02652030601113602
FISKESJÖ, G., 1985. The Allium test as a standard in environmental monitoring. Hereditas, vol. 102, no. 1, p. 99-112. PMid:3988545.

-, 1993. The Allium test in wastewater Monitoring. Environmental Toxicology and Water Quality, vol. 8, no. 3, p. 291-298. http:// dx.doi.org/10.1002/tox.2530080306

-, 1997. Allium test for screening chemicals; evaluation of cytological parameters. In WANCHENG, W., GORSUCH, JW. and HUGHES, JS. (Eds). Plants for Environmental Studies. Florida: CRC Press. p. 308-329.

GARCIA, MA., DUCK, S. and VENEGAS, W., 1995. Daño genético por efluentes industriales líquidos. Estudio in vitro. Boletín de la Sociedad de Biología, vol. 64, p. 95-100.

GRANT, WF., 1982. Chromosome aberration assays in Allium, a report of the US. Environmental Protection Agency GENE-TOX Program. Mutation Research, vol. 99, p. 273-291. PMid:7177154.

KOVACS, T., MARTEL, P., O'CONNOR, B., PARROT, J., MCMASTER, M., VAN DER KRAAK, G., MACLATCHY, D., VAN DEN HEUVEL, M. and HEWITT, L., 2011. Kraft mil effluent survey: Progress toward best management practices for reducing effects on fish reproduction. Environmental and Toxicology and Chemistry, vol. 30, no. 6, p. 1421-1429. PMid:21425320. http://dx.doi.org/10.1002/etc.526

KULSHRESHTHA, S., MATHUR, N. and BHATNAGAR, P., 2011. Handmade paper and cardboard industries: In health perspectives. Toxicology and Industrial Health, vol. 27, no. 6, p. 515-521. PMid:21343227. http://dx.doi.org/10.1177/0748233710391992

MITTERGGER, H., DA SILVA, J., ARENZON, A., SARAIVA, C., FERNANDES, IC. and PEGAS, JA., 2007. Evaluation of genotoxicity and toxicity of water and sediment samples from a Brazilian stream influenced by tannery industries. Chemosphere, vol. 67, p. 1211-1217. PMid:17157352. http://dx.doi.org/10.1016/j. chemosphere.2006.10.048

LEME, DM. and MARIN-MORALES, MA., 2008. Chromosome aberration and micronucleus frequencies in Allium cepa cells exposed to petroleum polluted water-A case study. Mutation Research, vol. 650, no. 1, p. 80-86. PMid:18068420.

-, 2009. Allium cepa test in environmental monitoring: A review on its application. Mutation Research, vol. 682, p. 71-81. PMid:19577002. http://dx.doi.org/10.1016/j.mrrev.2009.06.002

MACLATCHY, DL., MILESTONE, C., SHAUGHNESSY, KS., BELKNAP, AM., DUBE, MG. and HEWITT, LM., 2010. Reproductive Steroid responses in fish exposed to pulp mill condensates: An investigation of cause case study. Water Quality Research Journal of Canada, vol. 45, no. 2, p. 163-173.

MISIK, M., KNASMUELLER, S., FERK, F., CICHNA-MARKL, M., GRUMMT, T., SCHAAR, H. and KREUZINGER, N., 2011. Impact of ozonation on the genotoxic activity of tertiary treated municipal wastewater. Water Research, vol. 45, no. 12, p. 3681-3691.

MUSTAFA, Y. and ARIKAN, ES., 2008. Genotoxicity testing of quizalofop-P-ethyl herbicide using the Allium cepa anaphasetelophase chromosome aberration assay. Caryologia, vol. 61, no. $1,45-52$.

NUNES, E., DE LEMOS, C., GAVRONSKI, L., MOREIRA, TN., OLIVEIRA, N. and DA SILVA, J., 2011. Genotoxic assessment on river wáter using different biological systems. Chemosphere, vol. 84, no. 1, p. 47-53. PMid:21435689. http:// dx.doi.org/10.1016/j.chemosphere.2011.02.085 
OBERHOLSTER, PJ., BOTHA, AM. and CLOETE, TE., 2008. Biological and chemical evaluation of sewage water pollution in the Rietvlei nature reserve wetland area, South Africa. Environmental Pollution, vol. 156, no. 1, p. 184-192. PMid:18280017. http:// dx.doi.org/10.1016/j.envpol.2007.12.028

OHE, T., WATANABE, T. and WAKABAYASHI, K., 2004. Mutagens in surface waters: A review. Mutation Research, vol. 567, p. 109-149. PMid:15572284. http://dx.doi.org/10.1016/j. mrrev.2004.08.003

QUEVEDO, L., NORRIS, B., VENEGAS, W. and COLOMA, L., 1994. Disminución de la respuesta por efluentes industriales de una sinapsis neuroepitelial a la estimulación nerviosa en Caudiverbera caudiverbera. Boletín de la Sociedad de Biología, vol. 165 , p. $57-64$

RANK, J., LOPEZ, LC., NIELSEN, MH. and MORETTON, J., 2002. Genotoxicity of maleic hydrazide, acridine and DEHP in Allium cepa root cells performed by two different laboratories. Hereditas, vol. 136, no. 1, p. 13-8.

RIFFAT, A. and AHMAD, M., 2006. Allium cepa derived EROD as a potential biomarker for the presence of certain pesticides in water. Chemosphere, vol. 62, p. 527-537. PMid:16085274. http:// dx.doi.org/10.1016/j.chemosphere.2005.06.032

SIDDIQUI, AH., TABREZ, S. and AHMAD, M., 2011. Validation of plant based bioassays for the toxicity testing of Indian waters. Environmental Monitoring and Assessment, vol. 179, no. 1-4, p. 241-253. PMid:21042847. http://dx.doi.org/10.1007/s10661010-1732-9

STRÖMBERG, L., MORCK, R., SOUSA, P. and DAHLMAN, O., 1996. Effects of internal process changes and external treatment on effluent chemistry. In SERVOS, MR., MUNKITTRICK, KR., CAREY, JH. and VAN DER KRAAK, GJ. (Eds.). Environmental fate and effects of pulp and paper mill effluents. Deray Beach: St. Lucie Press. p. 3-20.
TÜRKOĞLU, Ş., 2007. Genotoxicity of five food preservatives tested on root tips of Allium cepa L. Mutation Research, vol. 626, p. 4-14. PMid:17005441.

VENEGAS, W., HERMOSILLA, I., GAVILÁN, J.F., ALMONACID, E. and VENEGAS, V., 1990. Amphibians and plants as model for detection of genotoxic and teratogenic agents present in continental water bodies of Chile. Revista Latinoamericana de Genética, vol. 1, p. 169-179.

VENEGAS, W., QUEVEDO, L. and COLOMA, L., 1994. Micronúcleo y cberraciones cromosómicas en Allium cepa, inducidas por efluentes industriales de la celulosa VIII Región, Chile. Boletín de la Sociedad de Biología, vol. 65, p. 31-42.

VENEGAS, W., GARCÍA, M., DUCK, S., ALARCÓN, M., WEIGERT, G. and HERMOSILLA, I., 1995 Actividad genotóxica de efluentes líquidos provenientes de la industria de la celulosa en Chile. Boletín de la Sociedad de Biología, vol. 66, p. 145-154.

VOGELBEIN, WK., FOURNIE, JW., VAN VELD, PA. and HUGGETT, RJ., 1990. Hepatic neoplasms in the mumichong Fundulus heteroclitus from a creosote contaminated site. Cancer Research, vol. 50, p. 5978-5986. PMid:2168287.

WANG, X., SHEN, L., HONGXIA, YU. and WANG, D., 2008. Toxicity evaluation in a paper recycling mill effluent by coupling bioindicator of aging with the toxicity identification evaluation method in nematode Caenorhabditis elegans. Journal of Environmental Science, vol. 20, p. 1373-1380. http://dx.doi. org/10.1016/S1001-0742(08)62235-4

XAVIER, CR., OÑATE, E., MONDACA, MA., CAMPOS, JL. and VIDAL, G., 2011. Genotoxic effects of Kraft pulp mill effluents treated by biological aerobic systems. Interciencia, vol. 36, no. 6, p. 412-416. 
